\title{
Using Digital Games for Enhancing EFL Grammar and Vocabulary in Higher Education
}

\author{
https://doi.org/10.3991/ijet.v15i20.16159 \\ Luz Castillo-Cuesta \\ Universidad Técnica Particular de Loja, Loja, Ecuador \\ lmcastillox@utpl.edu.ec
}

\begin{abstract}
The purpose of this study is to analyze the use of digital games to enhance English as a Foreign Language (EFL) grammar and vocabulary in the English Major of Universidad Técnica Particular de Loja, in southern Ecuador. A total of 68 students from B1 level, according to the Common European Framework of Reference for Languages (CEFR), participated in this study. All the participants were enrolled in two different classes of a Communicative Grammar course. A mixed-method approach was used to collect and analyze data in this study. Pre and post-questionnaires as well as writing rubrics were applied as instruments. Digital games were implemented throughout an academic term of 5 months in which students received permanent feedback. The results show that digital games were useful to improve learners' grammar in aspects concerning the use of modals, gerunds, and infinitives; also, students showed an improvement in their vocabulary knowledge, especially in topics related to jobs and education.
\end{abstract}

Keywords—Digital games, grammar, vocabulary, EFL writing, higher education.

\section{Introduction}

Teaching English as a Foreign Language in the era of globalization demands a big effort since the ability to communicate in English has become one of the most important skills to be developed by learners [1]. In this context, [2] remark that grammar and vocabulary constitute fundamental areas in language instruction. In fact, vocabulary knowledge is widely considered the building block of language learning since students' success usually depends on the amount of vocabulary they can use in communication [3]. Furthermore, vocabulary is a fundamental aspect in terms of mastering reading, listening, writing, and speaking language skills [4].

Similarly, grammar has also been considered a key area of language instruction. In this respect, [5] assert that grammar refers to the types of words and word groups that build sentences in any language. Considering the importance that both grammar and vocabulary have in EFL learning, [6] mention that the use of digital games is effective in contextualizing grammar and making it easier for students to learn vocabulary. Also, gamification enhances the teaching and learning process of a language and it 
empowers students with motivational skills, which is a fundamental aspect of EFL learning [7].

Currently, gamification is possible through the use of technology, which plays an essential role in providing language learners a valuable learning experience [8], [9]. Different alternatives can be used to implement digital gamification in EFL education. One of these alternatives is Educaplay, an innovative online platform that allows creating and sharing educational activities for enriching teaching and learning [10]. Thus, Educaplay is useful for designing digital games that can include crossword puzzles, matching games, cloze activities, interactive maps, among others [11]. This platform offers easy access and facilities for sharing activities and resources; therefore, EFL teachers can use it to create games and post them through their institutional virtual platforms.

Based on the aforementioned aspects, this study attempts to analyze the use of digital games to enhance EFL students' grammar and vocabulary. Thus, it shows the pedagogical possibilities of using digital games such as cloze activities, crossword puzzles, matching tasks, and unscramble sentences for improving the way students learn the target language, especially in writing skills. In this context, the following research questions have been considered:

How do students perceive the use of digital games to enhance grammar and vocabulary knowledge? And what is the impact of the use of digital games to enhance grammar and vocabulary knowledge?

\section{Literature Review}

\subsection{EFL teaching}

Since English is considered a lingua franca in our globalized world, teaching English as a foreign language is becoming increasingly important nowadays. Nevertheless, learning it might constitute a challenge in several contexts [12]. As [13] acknowledges, EFL teaching involves several factors that affect teachers and learners. These factors include the context, students' and teachers' expectations, planning, materials, learners' competence, and availability of resources.

In EFL teaching, listening, speaking, reading, and writing constitute the four skills for a language learner and thus play a vital role [14]. Therefore, teachers need to integrate them to help students communicate successfully in the target language [15]. As [16] state, "there is something about each of the language skills of listening, speaking, reading and writing that makes it different from the others". Thus, for the teaching of English to be effective, it is essential to give attention to each skill and make sure that students are developing their communicative competence and reaching the desired outcomes [17]. 


\subsection{Grammar and vocabulary issues in teaching EFL writing}

Writing is one of the four language skills and it is an essential aspect in language classes [18]. Certainly, this skill is necessary for EFL students to master, especially in occupational and academic issues [19]. In the same way, [20] asserts that writing is an important skill because it involves mastering multiple subskills to achieve a particular learning goal. However, teaching and learning writing at the university level has traditionally been a challenge [21]. In this context, the main difficulties faced by learners when writing in English can deal with limited grammatical knowledge [21]; lack of vocabulary to express their ideas, and difficulty to develop topics and establish coherence [22].

Since writing needs a certain amount of "linguistics awareness, vocabulary, writing conventions and grammar" [23], EFL instructors must encourage learners to enhance their language competence. In this regard, a combination of various writing strategies can be helpful to convey language knowledge, by making effective use of materials so that students have the opportunity to increase vocabulary knowledge, generate effective sentences, and be able to communicate in the target language [24].

\subsection{Technology and gamification in EFL teaching}

Technology, which is nowadays an inevitable part of our life, is also an integral element of the teaching-learning process [25], [26], [27]. Certainly, it has an impact on education because its use has enabled teachers to re-think what they are doing. Also, technology has beneficially changed the roles of teachers and has permitted more learner-centered activities to be carried out [28]. In the field of language learning, teachers and students can achieve positive results through the use of a wide range of technological tools [29].

Among the multiple benefits of using technology in the English language classroom, [30] affirm that it can help foreign language students strengthen their linguistic skills and learning attitude, as well as build their self-instruction strategies and selfconfidence. Furthermore, theory and practice in language learning can be effectively combined through the use of modern technology [31].

As [7] acknowledges, there is a strong connection between emergent technologies and gamification. Technological tools can enrich the classroom learning environment [32]; however, it is necessary to consider concrete pedagogical basis such as incorporating gamification in the classroom [33]. Gamification is a learning technique that transfers game mechanics to the educational field [34]; it is an informal umbrella term related to the use of video game elements in non-gaming systems to improve user experience and engagement [35]. Thus, games are useful in education because they provide a competitive platform for students to fully engage in learning [36].

\subsection{Digital games}

In the context of language learning, the use of gamification involves pedagogical approaches, methodologies, and strategies [7]. For the implementation of gamifica- 
tion, online platforms constitute one of the alternatives teachers can use in the EFL classroom to develop students' linguistic skills. Indeed, online platforms allow instructors to create digital games which are useful resources for learning a language [37]. Digital games are effective, fun, active, and encouraging ways to learn and provide feedback [38]; these constitute the modern version of game-based learning that teachers use to engage learners in meaningful and fun activities [39].

An innovative online platform that permits creating and sharing different types of educational activities and resources such as interactive maps, dialogue analysis, cloze activities, and learning games (quizzes, matching games, riddles, and crosswords) is Educaplay. This platform offers tutorials and makes it easy for a user to build activities that combine text, images, and audio. It also includes an extensive library of learning resources made by other teachers [10].

\subsection{Previous studies}

[40] conducted a study to understand both the beliefs and behaviors of pre-service EFL teachers in Germany regarding digital game-based language learning (DGBLL). The participants were 220 students who were enrolled in the Teaching English as a Foreign Language Major at Leuphana University. Validated instruments were administered to obtain the participants' behaviors and beliefs regarding both language learning and DGBLL. The findings revealed that the participants were limitedly engaged in DGBLL despite their beliefs about this method were positive. Although good perceptions were found to be inversely related to prior experience, engagement in game playing affects perceived English language skills and language learning strategies positively. The results have important implications in terms of DGBLL and help teachers understand the attitudes of "digital natives".

A study conducted by [41] analyzed the implementation of student-selected, entertainment-purposed digital games for foreign language teaching, and learning. A total of 16 EFL Korean students who were part of an educational technology course were involved in this study during a 15 -week semester. As part of the course activities, the participants were asked to play online games, visit gaming sites, complete instructional tasks aimed at improving language awareness, and generate possibilities for socialization into gaming discourses. It was found out that students showed language awareness in a variety of ways, but there were missed opportunities in developing student comprehension of language as a social medium. This study is a contribution to understanding important aspects of game-enhanced approaches to L2 teaching and learning.

[42] analyzed the effect of using online games for teaching vocabulary in an EFL context. The participants included 160 tenth grade Jordanian students who took vocabulary pre and post-tests. They were divided into four groups (two female and two male groups), which were purposefully selected. All the groups were taught vocabulary, the experimental two groups were taught using online games, while the two control groups were exposed to the conventional way such as memorizing. The results show that there were statistically significant differences in the post-test between the control and the experimental groups favoring the experimental group. However, there was no statistically significant difference in the students' achievement due to gender 
or to the interaction between gender and group. Researchers concluded that to achieve the most from vocabulary games, teachers should choose suitable games. Also, whenever a game is to be played, the number of students, proficiency level, cultural context, timing, learning topic, and classroom settings are factors that should be taken into consideration.

[43] studied the effectiveness of using online language games for enhancing ESL Malaysian learners' grammar. Thirty secondary school students participated in this study. The researchers used a quasi-experimental design and administered pre and post-tests. The intervention included the use of several online language games such as Socrative, PowerPoint Challenge Game, and Kahoot. Findings revealed that gamified learning was effective in terms of grammar achievement. Students got better results when they learned grammar through the use of online language games. Some of the factors involved in positive academic achievement included motivation and fun.

\section{$3 \quad$ Method}

\subsection{Participants}

This study included 68 participants at the B1 level, according to the CEFR. Their ages ranged between 20 and 23 years old. All the students were enrolled in two different classes of a Communicative Grammar course of the English Major at a private university in southern Ecuador.

\subsection{Instruments}

- A pre-questionnaire aimed to diagnose students' experience in using digital games for academic purposes. It included 10 questions that were administered through Survey Monkey

- Writing rubrics were used to assess aspects related to students' grammar and vocabulary knowledge

- A post-questionnaire to know about students' perceptions of the use of digital games for enhancing their grammar and vocabulary knowledge. This instrument consisted of 10 open-ended and close-ended questions and was applied using the Survey Monkey tool

\subsection{Procedure}

A mixed-method approach was used to collect and analyze data in this study. This approach emphasizes the combination of qualitative and quantitative methods to get a better understanding of the research problem [44].

At the initial stage, a pre-questionnaire was administered to know about students' previous knowledge in using digital games in the classroom. After analyzing students' responses, activities using digital games were carried out on a weekly basis for a period of twelve weeks; the games were designed in Educaplay and shared through the 
institutional Canvas platform. They included cloze activities, crossword puzzles, matching tasks, and unscramble sentences, which combined text, images, and audio. All of the aforementioned activities were aimed to reinforce students' grammatical and vocabulary knowledge which allowed them to enhance their writing skills. Learners received permanent feedback based on writing rubrics during this intervention stage. Then, a post-questionnaire was applied to identify the participants' perceptions of the use of digital games to enhance grammar and vocabulary knowledge. Finally, it is important to remark that all the instruments were piloted and validated with similar groups of students before their administration.

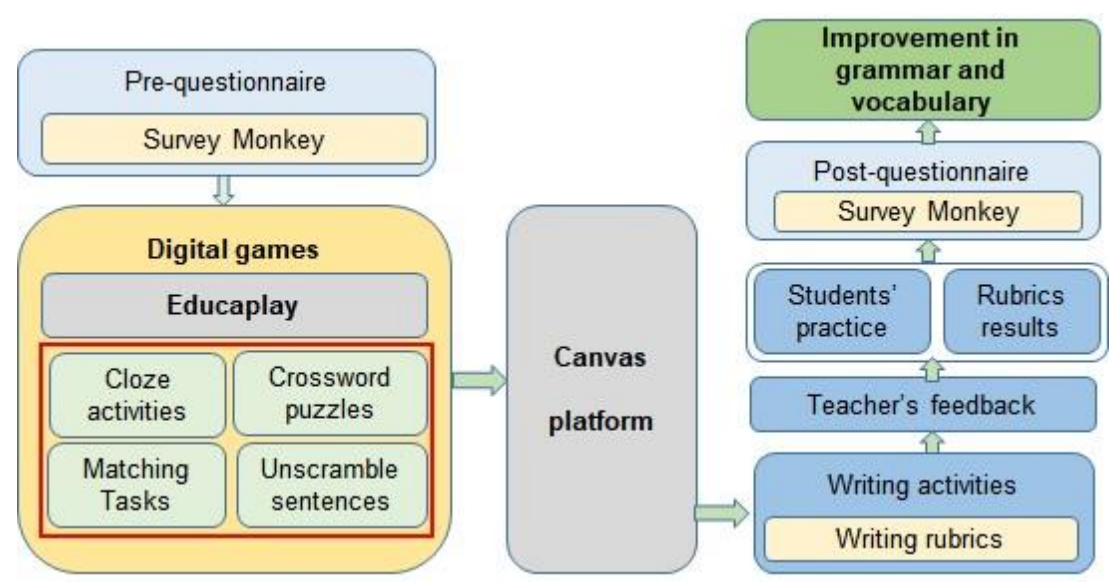

Fig. 1. Methodological procedure

\section{$4 \quad$ Results and Discussion}

The results of the pre-questionnaire evidenced that most of the students (72\%) had previously used digital games for academic purposes. However, none of them had been exposed to grammar and vocabulary games before taking this course. It was diagnosed that students needed to learn and practice some topics related to health, diet, languages, jobs, education, money, and etiquette. Also, it was evident that students had limited knowledge about some grammar structures including present perfect, modals, gerunds and infinities, and phrasal verbs.

After the intervention using digital games, the post-questionnaire results showed students' perceptions of the use of digital games for enhancing grammar and vocabulary knowledge as presented in Table 1. 
Table 1. Students' perceptions of the use of digital games to enhance grammar and vocabulary knowledge

\begin{tabular}{|c|l|c|c|c|c|c|}
\hline $\mathbf{N}^{\circ}$ & \multicolumn{1}{|c|}{ Statements } & $\begin{array}{c}\text { Strongly } \\
\text { agree } \\
(\%)\end{array}$ & $\begin{array}{c}\text { Agree } \\
(\%)\end{array}$ & $\begin{array}{c}\text { Neutral } \\
(\%)\end{array}$ & $\begin{array}{c}\text { Disagree } \\
(\%)\end{array}$ & $\begin{array}{c}\text { Strongly } \\
\text { disagree } \\
(\%)\end{array}$ \\
\hline 1 & $\begin{array}{l}\text { The use of digital games was helpful for } \\
\text { developing my English vocabulary } \\
\text { knowledge. }\end{array}$ & 62.30 & 24.37 & 10.63 & 2.70 & 0 \\
\hline 2 & $\begin{array}{l}\text { The use of digital games was helpful for } \\
\text { developing my English grammar } \\
\text { knowledge. }\end{array}$ & 59.19 & 31.14 & 6.25 & 3.42 & 0 \\
\hline 3 & $\begin{array}{l}\text { My interest in learning English was } \\
\text { increased through the use of digital } \\
\text { games. }\end{array}$ & 58.67 & 21.33 & 13.33 & 6.67 & 0 \\
\hline 4 & $\begin{array}{l}\text { The use of digital games motivated my } \\
\text { participation in the activities proposed on } \\
\text { the virtual platform. }\end{array}$ & 67.13 & 19.54 & 8.17 & 5.16 & 0 \\
\hline 5 & $\begin{array}{l}\text { The games designed in Educaplay al- } \\
\text { lowed my active and dynamic learning. }\end{array}$ & 59.43 & 28.42 & 9.22 & 2.93 & 0 \\
\hline 6 & $\begin{array}{l}\text { Access to digital games was easy through } \\
\text { the Canvas platform. }\end{array}$ & 62.46 & 19.44 & 11.33 & 6.77 & 0 \\
\hline 7 & $\begin{array}{l}\text { Digital games were easy to use and } \\
\text { offered immediate results. }\end{array}$ & 68.21 & 17.30 & 10.20 & 4.29 & 0 \\
\hline $\begin{array}{l}\text { The use of digital games facilitated my } \\
\text { teacher's feedback. }\end{array}$ & 54.84 & 22.14 & 18.76 & 4.26 & 0 \\
\hline $\begin{array}{l}\text { Using digital games was helpful to devel- } \\
\text { op my writing skills. }\end{array}$ & 69.33 & 16.35 & 12.12 & 2.20 & 0 \\
\hline
\end{tabular}

As it is shown in Table 1, the use of digital games was perceived as helpful for developing the participants' vocabulary knowledge. Thus, $86.67 \%$ of them strongly agreed and agreed with this statement, $10.63 \%$ neither agreed or disagreed, and 2.70 $\%$ disagreed. In this respect, [45] declare that learning vocabulary through online games is more effective than activity-based learning.

Regarding the use of digital games and its effectiveness for improving students' grammar knowledge, $59.19 \%$ of the participants mentioned that they strongly agree with this aspect, $31.14 \%$ agreed with it, while $9.67 \%$ were either neutral or in disagreement. As [43] affirm, students obtain better results when they learn grammar through the use of online language games; thus, gamified-learning is effective in terms of grammar achievement.

Respondents also expressed their perceptions of the use of digital games in Educaplay and their interest in learning English. Most of them (80\%) strongly agreed and agreed that the use of digital games increased their interest in learning this language. Nevertheless, $13.33 \%$ of the students did not express agreement or disagreement and only $6.67 \%$ disagreed. These findings are consistent with the research conducted by [11] who emphasizes that Educaplay games can arouse students' interest in learning English. 
Another interesting aspect was learners' motivation. To this respect, $67.13 \%$ of them strongly agreed and $19.54 \%$ agreed that the use of digital games motivated their participation to develop the activities proposed in their Canvas virtual platform; however, $13.33 \%$ of the participants were either neutral or in disagreement. Certainly, games are amusing and interesting, they are highly motivating; furthermore, they can be used to practice many types of communication for enhancing all language skills [46], [47].

As for the students' perceptions of Educaplay games, the majority of the participants $(87.85 \%)$ strongly agreed and agreed that these games allowed their active and dynamic learning, while $9.22 \%$ neither agreed or disagreed. Regarding this aspect, [48] asserts that Educaplay allows interaction so that the students have a learnercentered role in the learning process.

Regarding access to digital games, $62.46 \%$ of the students strongly agreed that it was easy for them to play games through the Canvas platform and $19.44 \%$ showed agreement with this aspect. Only $6.77 \%$ of the participants expressed disagreement. Even though the majority of learners asserted that it is easy to access to games, it is important to remark that teachers should use scaffolding strategies to help them appreciate the significance of games in enhancing language proficiency [49].

Concerning whether digital games were easy to use and offered immediate results, $68.21 \%$ of the participants strongly agreed, and $17.30 \%$ disagreed with this aspect, while a very low percentage (4.29\%) disagreed. Indeed, [50] remark that students' satisfaction is often considered as an index of learning outcomes caused by the effective use of educational technologies such as digital games.

With respect to the use of digital games as tools that facilitate teacher's feedback, $69.33 \%$ of the students strongly agreed and $16.35 \%$ disagreed with this statement. In this sense, [51] affirm that if learners are given permanent feedback about their performance, the use of digital games promotes deep learning.

As for the students' opinions about the use of digital games as helpful tools to develop their writing skills, $69.33 \%$ of them strongly agreed with this statement, and $16.35 \%$ agreed. A very low percentage $(2.20 \%)$ indicated that they disagree with this fact. Certainly, the use of games in the EFL classroom not only involves students in the learning process but also improves their English writing performance [52].

Table 2. Types of digital games

\begin{tabular}{|l|c|}
\hline \multicolumn{1}{|c|}{ Digital games } & Frequencies \\
\hline Cloze activities & $16 \%$ \\
\hline Crossword puzzles & $48 \%$ \\
\hline Matching tasks & $21 \%$ \\
\hline Unscramble sentences & $15 \%$ \\
\hline Total & $100 \%$ \\
\hline
\end{tabular}


When analyzing students' perceptions after using different types of digital games to enhance their EFL writing skills (table 2), $48 \%$ of them affirmed that they had a better performance in crossword puzzles, and $21 \%$ in matching tasks. These results are in agreement with [53], who also found that creating online crosswords is an important factor in engaging students in vocabulary active learning.

Table 3. Students' media scores in vocabulary

\begin{tabular}{|l|c|}
\hline \multicolumn{1}{|c|}{ Vocabulary type } & Mean \\
\hline Health & 8.56 \\
\hline Diet & 8.92 \\
\hline Languages & 7.84 \\
\hline Jobs & 9.34 \\
\hline Education & 9.20 \\
\hline Money & 7.24 \\
\hline Etiquette & 6.88 \\
\hline
\end{tabular}

Table 4. Students' media scores in grammar

\begin{tabular}{|l|c|}
\hline \multicolumn{1}{|c|}{ Grammar aspects } & Mean \\
\hline Present perfect & 7.32 \\
\hline Modals & 9.22 \\
\hline Gerunds and infinitives & 8.66 \\
\hline Phrasal verbs & 6.48 \\
\hline
\end{tabular}

Once students used the digital games designed for this course, writing activities were assessed through rubrics. Regarding vocabulary, the media score in vocabulary topics related to "Jobs" and "Education" were the most representative in terms of students' improvement. This result might be related to previous experience with these topics; furthermore, it is necessary to remark that "Education" belongs to their field of study. It was also evident that the topics in which students might have found certain difficulties were "Money" and "Etiquette" because of their lack of previous practice.

As for grammar, "Modals" as well as "Gerunds and infinitives" were the aspects in which the mean score was higher. To this respect, it is necessary to acknowledge that these correspond to recycled contents from lower levels which constitute the basis for building new grammatical knowledge. On the other hand, "Present perfect" and "Phrasal verbs" were the aspects in which students encountered certain difficulties because these structures have many notions, variations, and uses. 


\section{Conclusion}

The use of digital games helped the participants enhance their grammar and vocabulary knowledge since they demonstrated a better performance when using crossword puzzles and matching games aimed at developing these sub-skills, which is evident in students' perceptions of their improvement in EFL writing.

Students perceived the use of digital games in Educaplay as motivating for learning English and developing the activities proposed in their Canvas virtual platform. These games promoted students' active and dynamic learning since Educaplay was helpful to create and share engaging educational activities, thus increasing their interest in learning the target language.

Digital games were easy-to-access activities since they were available for students through the Canvas platform, which was a significant factor that allowed students' participation. Furthermore, Educaplay digital games were easily used, did not require additional registration, and offered immediate results.

The use of digital games favored teachers' permanent feedback based on writing rubrics. These rubrics helped them identify students' strengths and weaknesses regarding grammar and vocabulary. The grammar aspects in which students had a better performance were related to the use of modals, gerunds, and infinitives. As for vocabulary, the topics that evidenced better results were jobs and education.

\section{Acknowledgement}

I would like to thank Universidad Técnica Particular de Loja and the "EFL Learning, Teaching, and Technology" Research Group for the academic and economic support that facilitated this study.

\section{$7 \quad$ References}

[1] H.-Y. Yeh, Y.-T. Tsai, and C.-K. Chang, "Android app development for teaching reduced forms of EFL listening comprehension to decrease cognitive load," in 2017 International Conference of Educational Innovation through Technology (EITT), 2017, pp. 316-321. https://doi.ieeecomputersociety.org/10.1109/EITT.2017.82. https://doi.org/10.1109/eitt.20 $\underline{17.82}$

[2] E. Simon and M. Taverniers, "Advanced EFL learners' beliefs about language learning and teaching: a comparison between grammar, pronunciation, and vocabulary," English Stud., vol. 92, no. 8, pp. 896-922, 2011. https://doi.org/10.1080/0013838X.2011.604578

[3] F. Deris and N. Shukor, "Vocabulary Learning Through Mobile Apps: A Phenomenological Inquiry of Student Acceptance and Desired Apps Features," 2019. https ://doi.org/10.3991/ijim.v13i07.10845

[4] F. Al-Khasawneh, "The Impact of Vocabulary Knowledge on the Reading Comprehension of Saudi EFL Learners,” J. Lang. Educ., vol. 5, no. 3, pp. 24-34, 2019. https://doi.org/10.1 $\underline{7323 / \mathrm{jle} .2019 .8822}$ 
[5] M. Yavarian, M. A. KORD, A. KORD, and A. AZIZI, "The effect of diary writing on learning grammar by intermediate EFL learners,” Res. J. English Lang. Lit. Int. J., vol. 3, no. 4, pp. 184-188, 2015.

[6] S. Jalali and M. Dousti, "Vocabulary and grammar gain through computer educational

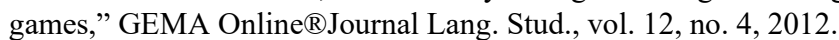

[7] J. F. F. Flores, "Using gamification to enhance second language learning," Digit. Educ. Rev., no. 27, pp. 32-54, 2015.

[8] R. Ybarra and T. Green, "Using technology to help ESL/EFL students develop language skills," Internet TESL J., vol. 9, no. 3, pp. 1-5, 2003. http://iteslj.org/Articles/YbarraTechnology.html

[9] P. Jaiswal, "Integrating Educational Technologies to Augment Learners' Academic Achievements,” Int. J. Emerg. Technol. Learn., vol. 15, no. 02, pp. 145-159, 2020. https:// doi.org/10.3991/ijet.v15i02.11809

[10] L. Correa, "Plataforma Educaplay, como herramienta para la creación de actividades educativas para el refuerzo académico." Available: http://www.virtualepn.edu.ec/evento2013/Presentaciones/LeticiaCorreaEducaplay.pdf

[11] N. R. Pérez Salazar, "Influencia del uso de la plataforma Educaplay en el desarrollo de las capacidades de comprensión y producción de textos en el área de inglés en alumnos de 1er año de secundaria de una institución educativa particular de Lima.," 2014. https://doi.org/ 10.17162/au.v6i1.115.s11

[12] P. Cabrera-Solano, P. Gonzalez-Torres, L. Solano, L. Castillo-Cuesta, and J. Jiménez, "Perceptions on the Internal Factors Influencing EFL Learning: A Case of Ecuadorian Children.," Int. J. Instr., vol. 12, no. 4, 2019. https://doi.org/10.29333/iji.2019.12424a

[13] A. M. F. Barcelos, "Narrativas, crenças e experiência de aprender inglês," Rev. Ling. Ensino, vol. 9, no. 2, pp. 145-175, 2006.

[14] L. M. Sadiku, "The importance of four skills reading, speaking, writing, listening in a lesson hour,” Eur. J. Lang. Lit., vol. 1, no. 1, pp. 29-31, 2015. https://doi.org/10.26417/ej 1s.v1i1.p29-31

[15] A. Akram and A. Malik, "Integration of language learning skills in second language acquisition," Int. J. Arts Sci., vol. 3, no. 14, pp. 231-240, 2010. http://openaccesslibrary.org/images/PRV/27_Aneela_Akram.pdf

[16] I. S. P. Nation and J. Newton, Teaching ESL/EFL listening and speaking. Routledge, 2008. https://doi.org/10.4324/9780203891704

[17] R. DeKeyser, Practice in a second language: Perspectives from applied linguistics and cognitive psychology. Cambridge University Press, 2007.

[18] M. Kharis, M. Ebner, P. H. Wijayati, E. Hidayat, and L. Afifah, "Microblogging with Padlet: Students' New Writing Experience on A2--B1 Common European Framework of Reference for Languages (CEFR)," Int. J. Emerg. Technol. Learn., vol. 15, no. 01, pp. 176-187, 2020. https://doi.org/10.3991/ijet.v15i01.11804

[19] M. A. Ghufron and S. Ermawati, "The Strengths and Weaknesses of Cooperative Learning and Problem-Based Learning in EFL Writing Class: Teachers' and Students' Perspectives.," Int. J. Instr., vol. 11, no. 4, pp. 657-672, 2018. https://doi.org/10.12973/iji. 2018.11441a

[20] Q. Xie, "Diagnosing university students' academic writing in English: Is cognitive diagnostic modelling the way forward?," Educ. Psychol., vol. 37, no. 1, pp. 26-47, 2017. https://doi.org/10.1080/01443410.2016.1202900

[21] M. A. Alharbi, "Saudi Arabia EFL university students' voice on challenges and solution in learning academic writing," Indones. J. Appl. Linguist., vol. 8, no. 3, pp. 576-587, 2019. https://doi.org/10.17509/ijal.v8i3.15276 
[22] A. Terraschke and R. Wahid, "The impact of EAP study on the academic experiences of international postgraduate students in Australia,” J. English Acad. Purp., vol. 10, no. 3, pp. 173-182, 2011. https://doi.org/10.1016/j.jeap.2011.05.003

[23] A. A. Sabti, S. Rashid, and A. S. Hummadi, "Interrelationships between Writing Anxiety Dimensions and Writing Goal Orientation among Iraqi EFL Undergraduates," Int. J. Instr., vol. 12, no. 4, pp. 529-544, 2019. https://doi.org/10.29333/iji.2019.12434a

[24] C. Han, "The effectiveness of application of writing strategies in writing instruction," J. Lang. Teach. Res., vol. 8, no. 2, pp. 355-361, 2017. http://dx.doi.org/10.17507/jltr.0802.19

[25] A. W. T. Bates and A. Sangra, Managing technology in higher education: Strategies for transforming teaching and learning. John Wiley \& Sons, 2011.

[26] T. Han and F. Keskin, "Using a mobile application (WhatsApp) to reduce EFL speaking anxiety,” Gist Educ. Learn. Res. J., no. 12, pp. 29-50, 2016. https://doi.org/10.26817/1692 5777.243

[27] G. Dudeney and N. Hockly, "How to teach English with technology," 2007.

[28] M. M. Yunus, "Innovation in education and language learning in 21st Century," J. Sustain. Dev. Educ. Res., vol. 2, no. 1, pp. 33-34, 2018. https://doi.org/10.17509/jsder.v2i1.12355

[29] N. Azmi, "The benefits of using ICT in the EFL classroom: From perceived utility to potential challenges,” J. Educ. Soc. Res., vol. 7, no. 1, pp. 111-118, 2017. https://doi.org/ 10.5901/jesr.2017.v7n1p111

[30] C.-C. Lai and W. A. Kritsonis, "The advantages and disadvantages of computer technology in second language acquisition.," Online Submiss., vol. 3, no. 1, 2006.

[31] B. B. Nomass, "The Impact of Using Technology in Teaching English as a Second Language. English Language and Literature Studies, 3 (1), 111--116," Adv. English Linguist. (AEL), I, vol. 2, pp. 25-29, 2013. https://doi.org/10.5539/ells.v3n1p111

[32] C. Guetl, V. Chang, A. Edwards, and S. Boruta, "Flexible and affordable foreign language learning environment based on Web 2.0 technologies," Int. J. Emerg. Technol. Learn., vol. 8, no. 2, pp. 16-28, 2013. https://doi.org/10.3991/ijet.v8i2.2488

[33] J. Simões, R. D. Redondo, and A. F. Vilas, "A social gamification framework for a K-6 learning platform,” Comput. Human Behav., vol. 29, no. 2, pp. 345-353, 2013. https://doi. org/10.1016/j.chb.2012.06.007

[34] W. Alhalafawy and M. Zaki, "The effect of mobile digital content applications based on gamification in the development of psychological well-being," 2019. https://doi.org/10.39 91/ijim.v13i08.10725

[35] S. Deterding, M. Sicart, L. Nacke, K. O'Hara, and D. Dixon, "Gamification. using gamedesign elements in non-gaming contexts," in CHI'11 extended abstracts on human factors in computing systems, 2011, pp. 2425-2428. https://doi.org/10.1145/1979742.1979575

[36] E. D. Mekler, S. Rank, S. T. Steinemann, M. V Birk, and I. Iacovides, "Designing for emotional complexity in games: The interplay of positive and negative affect," in Proceedings of the 2016 annual symposium on computer-human interaction in play companion extended abstracts, 2016, pp. 367-371. https://doi.org/10.1145/2968120.29681 $\underline{26}$

[37] Y. Turgut and P. I.Irgin, "Young learners' language learning via computer games," Procedia-Social Behav. Sci., vol. 1, no. 1, pp. 760-764, 2009. https://doi.org/10.1016/j.sbs pro.2009.01.135

[38] R. Kanthan and J.-L. Senger, "The impact of specially designed digital games-based learning in undergraduate pathology and medical education," Arch. Pathol. Lab. Med., vol. 135, no. 1, pp. 135-142, 2011.

[39] R. Dellos, "Kahoot! A digital game resource for learning," Int. J. Instr. Technol. Distance Learn., vol. 12, no. 4, pp. 49-52, 2015. 
[40] C. Blume, "Games people (don't) play: An analysis of pre-service EFL teachers' behaviors and beliefs regarding digital game-based language learning," Comput. Assist. Lang. Learn., vol. 33, no. 1-2, pp. 109-132, 2020. https://doi.org/10.1080/09588221.2018.155 $\underline{2599}$

[41] L. McNeil, "Implementing digital game-enhanced pedagogy: Supportive and impeding language awareness and discourse participation phenomena," ReCALL, vol. 32, no. 1, pp. 106-124, 2020. https://doi.org/10.1017/S095834401900017X

[42] W. Muhanna, "Using online games for teaching English vocabulary for Jordanian students learning English as a foreign language," J. Coll. Teach. Learn., vol. 9, no. 3, p. 235, 2012. https://doi.org/10.19030/tlc.v9i3.7178

[43] H. Hashim, R. M. Rafiq, M. Md Yunus, and others, "Improving ESL Learners' Grammar with Gamified-Learning,” Arab World English J. Spec. Issue CALL, no. 5, 2019. https:// doi.org/10.24093/awej/call5.4

[44] J. W. Creswell, Educational research: Planning, conducting, and evaluating quantitative. Prentice Hall Upper Saddle River, NJ, 2002.

[45] F. W. M. Yip and A. C. M. Kwan, "Online vocabulary games as a tool for teaching and learning English vocabulary,” EMI. Educ. Media Int., vol. 43, no. 3, pp. 233-249, 2006. https://doi.org/10.1080/09523980600641445

[46] E. Aydan, "Games for vocabulary presentation," Internet TESL J., vol. 6, no. 6, 2000.

[47] T. Uiphanit, P. Bhattarakosol, K. Suanpong, S. Iamsupasit, and C. Wongwan, "Chibumons: A Positive Effect On Game to Undergraduate Students," Int. J. Emerg. Technol. Learn., vol. 15, no. 01, pp. 222-230, 2020. https://doi.org/10.3991/ijet.v15i01.11 $\underline{502}$

[48] M. K. López Pincay, "Desarrollo de Contenidos y Destrezas de Morfosintaxis Mediante el Empleo de los Software: Educaplay, J Clik, Scratch y Smart Board, para el Fortalecimiento del Lenguaje Oral y Escrito en los Estudiantes de Cuarto a Séptimo Año de Educación Básica," Quito: Universidad Israel, 2012, 2012. https://doi.org/10.46377/dilemas.v34i1.22 $\underline{10}$

[49] A. IcSahin Klizlil, "EFL learners in the digital age: An investigation into personal and educational digital engagement," RELC J., vol. 48, no. 3, pp. 373-388, 2017. https://doi. org/10.1177/0033688216684285

[50] R. Li, Z. Meng, M. Tian, Z. Zhang, and W. Xiao, "Modelling Chinese EFL learners' flow experiences in digital game-based vocabulary learning: the roles of learner and contextual factors," Comput. Assist. Lang. Learn., pp. 1-22, 2019. https://doi.org/10.1080/09588221. $\underline{2019.1619585}$

[51] S. Erhel and E. Jamet, "Digital game-based learning: Impact of instructions and feedback on motivation and learning effectiveness," Comput. Educ., vol. 67, pp. 156-167, 2013. https://doi.org/10.1016/j.compedu.2013.02.019

[52] C.-J. Lin and G.-J. Hwang, "A flipped classroom approach to supporting game-based learning activities for EFL business writing course," in 3rd Annual International Seminar on Transformative Education and Educational Leadership (AISTEEL 2018), 2018. https:// doi.org/10.2991/aisteel-18.2018.31

[53] M. Tasnimi and M. A. Ravari, "The Impact of Using Google Concordancer and Creating Online Crosswords on EFL Learners' Self-Regulation in Vocabulary Learning: A Discovery Learning Approach,” Int. J. Stud. English Lang. Lit., vol. 4, no. 7, pp. 81-86, 2016. https://doi.org/10.20431/2347-3134.0407013 


\section{Author}

Luz Castillo-Cuesta is a Master of Science in Teaching English as a Foreign Language at Nova Southeastern University of Florida, U.S.A. Master of Teaching English as a Foreign Language at Universidad Técnica Particular de Loja (UTPL), Ecuador. Undergraduate studies in Education: EFL teaching, Professor for thirteen years at UTPL, former coordinator of the English Major and the Academic Board of the English Major. Member of the Research Group EFL Learning, Teaching and Technology and the EFL Teachers' Network in Ecuador. Linguistics Doctoral student at Universidad Nacional del Rosario, Argentina. Co-author of different indexed articles and four book chapters.

Article submitted 2020-06-08. Resubmitted 2020-07-01. Final acceptance 2020-07-02. Final version published as submitted by the authors. 